\title{
Література:
}

1. Кримінальний процесуальний кодекс України: Закон України від 13.04. 2012p. № 4651-VI. URL: https://zakon.rada.gov.ua/laws/show/465117\#Tеxt (дата звернення 01.04.2021).

2. Віденська конвенція про дипломатичні зносини: Конвенція від 18.04.1961 p. URL: https://zakon.rada.gov.ua/laws/show/995_048\#Text (дата звернення 01.04.2021).

3. Віденська конвенція про консульські зносини: Конвенція від 24.04.1963 p. URL: https://zakon.rada.gov.ua/laws/show/995_047\#Text (дата звернення 01.04.2021).

DOI https://doi.org/10.30525/978-9934-26-074-2-69

\section{КРИМІНАЛЬНО-ПРОЦЕСУАЛЬНЕ ДОКАЗУВАННЯ: УКРАЇНА, ФРН, США}

\author{
Савчук М. А. \\ orcid.org/0000-0002-3467-4690
}

викладач кафедри кримінально-правових дисииплін

Криворізький навчально-науковий інститут

Донеиького юридичного інституту

Мінстерства внутрішніх справ Украйни,

адвокат

м. Кривий Ріг, Дніпропетровська область, Україна

\author{
Часова T. 0. \\ orcid.org/0000-0002-0293-6123 \\ кандидат юридичних наук,
}

дочент кафедри кримінального права, прочесу та криміналістики

Академії прачі, сочіальних відносин і туризму,

адвокат

м. Київ, Украӥна

Центральне місце у кримінально-процесуальному праві відведено інституту доказування. Доказування $\epsilon$ складним за процедурою механізмом, який складається 3 декількох етапів: збирання, оцінка та застосування доказів під час розслідування. Дотримання належної процедури фактично допомагає встановити що саме належить до категорії доказів, яким чином їх слід процесуально закріпити та в подальшому, щоб це призвело до їх використання у судовому процесі. 
Слід зазначити, що досвід країн, серед яких ФРН та США, необхідно досліджувати та позитивні моменти процедурної діяльності адаптовувати під українські реалії доказування.

Наукові та практичні працівники приділяють увагу розгляду питанням кримінально-процесуального доказування, в тому числі дослідженню процесу доказування в ФРН та США. До числа таких науковців слід віднести: Вапнярчук В., Кубарєв І.В., Молдаван А.В., Савченко В.А., Садова Т.В. При цьому, низка питань потребує наукового уточнення та додаткового дослідження.

Вапнярчук В. особливу увагу приділяє дослідженню терміна «стандарт доказування», зазначаючи, що в Україні немає єдиного підходу до визначення суті питання, але для англосаксонської правової системи відіграє важливу роль. У США, виділяють стандарт доказування, який називають «ясні та переконливі докази» (clear and convincing evidence). Суть його в тому, що сторона повинна переконати присяжних (або суддю), що достовірність факту, який розглядається, є досить ймовірною, або викликати в них тверде переконання, що факт правдивий [1, с. 102]. У КПК України, як і в більшості країн континентальної Європи, сприйнятий, так званий, суб'єктивний стандарт доказування «за внутрішнім переконанням», який полягає в тому, що тягар доказування визначає зобов'язання щодо визнання чи невизнання фактів встановленими (тобто, по суті, є об'єктивним правилом доказування) $[1$, c. 106$]$.

Кубарєв І.В. наголошує, що позитивним $є$ досвід запозичення практики розвинутих країн, яка внаслідок правильного та однозначного застосування здатна сприяти значній процесуальній економії під час розслідування тяжких й особливо тяжких злочинів, наприклад в частині укладення угод про визнання винуватості [2, с. 193].

Доказування у ФРН має свої особливості в рамках проведення розслідування, серед яких: чітке та вільне доказування. Чітке доказування має на меті встановлення фактів, які мають значення для вини та покарання. Чітке доказування характеризується суворим дотриманням норм доказового права. Вільне доказування має на меті вірогідність встановлення фактів та не має необхідності у застосуванні засад кримінального процесу. Особливістю $є$ те, що стадія попереднього розслідування не регламентована кримінально-процесуальними нормами [3, c. 147].

У США тягар доказування покладено на сторону обвинувачення, яка повинна довести: 1) обвинувачений вчинив злочин, що розглядається; 2) у обвинуваченого існував злочинний намір щодо кожної 3 інкримінованих злочинних дій. Обвинувачений, в свою чергу, повинен 
оспорювати доводи обвинувачення; у разі виявлення процедурних порушень тягар доведення покладено на обвинуваченого.

Обов'язок доказування за законом ФРН на стадії попереднього розслідування покладається на прокуратуру, в судовому провадженні тільки на суд. КПК України обов’язок доказування показує на слідчого, прокурора, інколи - потерпілого.

У кримінальному процесі США експертизу може провести будь-яка зі сторін процесу за власною ініціативою. Якщо одна зі сторін провела експертизу, то інша сторона процесу за власною ініціативою. Якщо одна зі сторін провела експертизу, то інша сторона процесу має рівні права провести контр експертизу. У кримінальному процесі ФРН діяльність експерта визначається концепцією, згідно з якою експерт не лише засіб доказування, але й помічник судді; він несе відповідальність за розслідування і вирішення справи [3, с. 158].

Законодавство ФРН передбачає обов'язкове призначення експертизи в таких випадках: для встановлення причин смерті; для встановлення психічного стану обвинуваченого; за підозрою в отруєнні; при підробці грошей та інших цінних паперів [3, с. 151]. За законодавством України кожна сторона кримінального провадження має право надати суду висновок експерта, який грунтується на його наукових технічних та інших спеціальних знаннях [3, с. 145].

У ФРН до джерел доказів відносять: показання свідків; показання обвинуваченого; висновки експертів; речові докази; документи. Законодавство США джерелами доказів визначає: показання свідків, потерпілого, підозрюваного, обвинувачених, експертів тощо. В свою чергу, КПК України визначає доказами: показання, речові докази, висновки експертів, документи.

У США речові докази - це об'єкти матеріального світу, які були знаряддями чи засобами вчинення злочину. Під речовими доказами в кримінальному процесі ФРН розуміють об'єкти огляду (всі речі, живі особи, трупи) та документи (будь-який предмет, на якому зафіксована думка за допомогою письмових знаків.

КПК України передбачає, що речовими доказами є матеріальні об’єкти, які були знаряддям вчинення кримінального правопорушення, зберегли на собі його сліди або містить інші відомості, які можуть бути використані як доказ факту чи обставин, що встановлюються під час кримінального провадження, в тому числі предмети, що були об’єктом кримінального кримінально протиправних дій (гроші цінності та інші речі набуті кримінально протиправним шляхом). Документи є речовими доказами [4]. 
Процес доказування безпосередньо пов'язаний з дотриманням прав і свобод у кримінальному провадженні. Важливість цього пояснюється сутністю кримінально-процесуального права, яка виступає тією галуззю права, яка містить найбільшу кількість заходів примусу та тих процесуальних дій, що в процесі збирання доказів обмежують свободи та права людини і громадянина [5].

Доцільно зробити висновок, що впровадження позитивного досвіду розвинутих країн в кримінально-процесуальне законодавство України слід вважати етапом вдосконалення таких процесуальних норм. Саме тому, окрему увагу необхідно приділяти вивченню кримінальнопроцесуального доказування ФРН та США, в частині збирання, закріплення, оцінки та використання доказів. Розроблення злагодженого механізму доказування $\epsilon$ окремим пріоритетом законодавчих органів, а його застосування вирішить проблеми кримінально-процесуального доказування на практиці.

\section{Література:}

1. Вапнярчук В. Стандарт кримінально-процесуального доказування. / Вісник Національної академії правових наук України № 1 (80), 2015. - C. $100-112$

2. Кубарєв I.В., Барган С.С. Закордонний досвід регламентації співпраці підозрюваного зі стороною обвинувачення. / Правовий часопис Донбасу № 3 (72), 2020. - С. 188-195

3. А.В. Молдаван, В.А. Савченко, Т.В. Садова. Кримінальний процес: Україна, ФРН, США. Навчальний посібник. - К: Алерта, 2014. -334 c.

4. Кримінальний процесуальний кодекс України: Відомості Верховної Ради України (ВВР), 2013, № 9-10, № 11-12, № 13. Ст.88. URL: https:// zakon.rada.gov.ua/laws/show/4651-17.

5. Доказування у кримінальному провадженні: навч.-практ. посібн. / кол. авт. - К.: Національна академія прокуратури України, 2017. - 346 с. 